\title{
THE CONRADIAN 'SHADOW-LINE' IN SELECTED WORKS BY STANISLAW LEM
}

\author{
Daniel Vogel \\ State University of Applied Sciences in Racibórz
}

\begin{abstract}
Joseph Conrad wrote The Shadow-Line. A Confession at the end of 1916, when Europe was in the middle of the Great War. As he mentions in the "Author's Note" (written in 1920), the purpose of the work was to present certain events connected with the passage from youth to maturity. However, in the course of time the expression "shadow line" gained more universal meaning, and now the phrase "to cross the shadow-line" refers not only to crossing the border between youth and maturity, but to passing from one period of life into another. The literary output of Joseph Conrad, had considerable influence not only on his contemporaries or immediate followers, but on the modern artists as well. One of them was Stanisław Lem-philosopher, essayist, author of excellent Science-Fiction novels and short stories, peopled with such characters as Ijon Tichy, Professor Tarantoga or the unforgettable Pirx the pilot. Although in his works Lem, save a few exceptions, does not make direct references to Joseph Conrad and his fiction, Conradian motifs can be traced in most of his novels. One of them is the motif of crossing the shadow-line, noticeable in such works as Return from the Stars, The Invincible, Tales of Pirx the Pilot. The article shows how the author of Solaris used the motif of Conradian "shadow-line" to present the difficult moments, decisions and dilemmas of his protagonists.
\end{abstract}

Keywords: Joseph Conrad, Stanisław Lem, the shadow line, first command, return from the stars, the invincible, Pirx the pilot, loneliness of the commander, responsibility of the commander, loyalty of crew, marine fiction, space voyage

The Shadow Line - which is one of Joseph Conrad's later works - and the short stories Falk and The Secret Sharer-from Conrad's middle period - comprise the socalled "Bangkok Trilogy". ${ }^{1}$ It is the tale of a young captain who gets his first command and faces unforeseeable obstacles. The story starts with the incomprehensible decision of the chief character to resign from the apparently good position of first officer, "chief", on a small steamer trading "among dark islands on a blue reef-scarred

${ }^{1}$ It is the suggestion of Yasuko Shidara mentioned in "Conrad and Bangkok" [in:] Journey, Myths and the Age of Travel: Joseph Conrad's Era, ed. K. Hansson, Karlskrona: University of Karlskrona, 1998, pp. 76-96. Norman Sherry notices that three works, i.e. Falk, The Shadow-Line and The End of the Tether contain the same basic situation: a ship anchored in Bangkok and a search for a captain to take command. Cf. N. Sherry, Conrad's Eastern World, Cambridge: Cambridge UP, 1966, pp. 212-214. 
sea". ${ }^{2}$ The protagonist and narrator of the tale explains, however, that such things happen when one is young, and that they do not require any specific explanation:

It was as though all unknowing I had heard a whisper or seen something, Well-perhaps! One day I was perfectly right and the next everything was gone - glamour, flavour, interest, contentment - everything. It was one of these moments, you know. The green sickness of late youth descended on me and carried me off. Carried me off that ship, I mean. ${ }^{3}$

Having no precise plans for the forthcoming days, he stays in the Officers' Home for a short time under the pretext of waiting for a ship which will take him to Europe. He meets a few "men of the sea" there-naval officers and the experienced Captain Giles, thanks to whom he becomes the captain of a small sailing ship anchored in Bangkok, which he is supposed to bring to the home harbour in Singapore.

This nomination gives our protagonist, who initially seems to be tired of the sea, wings and power:

A ship! My ship! She was mine, more absolutely mine for possession and care than anything in the world; an object of responsibility and devotion. She was there waiting for me, spell-bound, unable to move, to live, to get out into the world (till I came), like an enchanted princess. Her call had come to me as if from the clouds. I had never suspected her existence. I didn't know how she looked, I had barely heard her name, and yet we were indissolubly united for a certain portion of our future, to sink or swim together!

A sudden passion of anxious impatience rushed through my veins, gave me such a sense of the intensity of existence as I have never felt before or since. I discovered how much of a seaman I was, in heart, in mind, and, as it were, physically - a man exclusively of sea and ships; the sea the only world that counted, and the ships, the test of manliness, of temperament, of courage and fidelity—and of love. ${ }^{4}$

The above quotation discloses the unique magic of the first command, which our new captain perceives as a fulfillment of his youthful dreams. However, when he gets on site it appears that the situation differs considerably from his earlier imaginations and expectations. The magic is gone, the new captain has to face reality and while on board encounters unexpected and extraordinary challenges: the chief mate's illness, difficulties with leaving the harbour, sluggish sailing in the Siamese Bay and periods of complete silence, malaria which incapacitates most of the crew and which cannot be cured due to the lack of quinine, and finally his own physical and mental exhaustion (apart from the captain the only man able to do the work is Ransom, whose strength is quite limited by his weak heart). In consequence, the cumulation of difficulties becomes an incredible test for the young captain, who leaves his youth on shore, and together with his ship and seamen, for whom he is now responsible, sails into maturity thus crossing the titular "shadow-line". When he finally gets to Singapore, even though the voyage has taken only a few weeks, our protagonists feels "old", which he emphasizes in this short conversation with Captain Giles:

${ }^{2}$ J. Conrad, "The Shadow-Line: A Confession" [in:] idem, Three Sea Stories, Ware: Wordsworth Editions Limited, 1998, p. 160.

${ }^{3}$ Ibid.

${ }^{4}$ Ibid., p. 184. 
"You must feel jolly well tired by this time."

"No," I said. "Not tired. But I'll tell you, Captain Giles, how I feel. I feel old. And I must be. All of you on shore look to me just a lot of skittish youngsters that have never known a care in the world."

He didn't smile. He looked insufferably exemplary. He declared:

"That will pass. But you do look older-it's a fact."

Giles also explains what, in fact, command of a responsible captain is connected with, and what it means to be a mature man:

"And there's another thing: a man should stand up to his bad luck, to his mistakes, to his conscience and all that sort of thing. Why — what else would you have to fight against."

I kept silent. I don't know what he saw in my face but he asked abruptly:

"Why-you aren't faint-hearted?"

"God only knows, Captain Giles," was my sincere answer.

"That's all right," he said calmly. "You will learn soon how not to be faint-hearted. A man has got to learn everything — and that's what so many of them youngsters don't understand."

Following the fortunes and misfortunes of the captain in The Shadow-Line one notices the similarities between the protagonist and the author himself, particularly if we take into account Conrad's own command of the barque Otago. However, the very text of the masterpiece cannot be treated as autobiographical. As is the case with other works, the author mingles his own experience with the experiences of other people; he also embellishes it with imagined motifs and characters. Conrad himself admits in the "Author's Note" that:

[A]s a matter of fact it is a personal experience seen in perspective with the eye of the mind and coloured by that affection one can't help feeling for such events of one's life as one has no reason to be ashamed of [...] The effect of perspective in memory is to make things loom large because the essentials stand out isolated from their surroundings of insignificant daily facts which have naturally faded out of one's mind.

Nevertheless, Conrad's first and only command was a very important episode in the author's life; this was the peak of his maritime career, which was to last only a few more years. ${ }^{8}$ The command of the Otago is presented accurately by all key biographers of Joseph Conrad, including Zdzisław Najder, John Stape, Norman Sherry. First, on the $4^{\text {th }}$ January 1888 31-year-old Conrad resigns from the post of first officer on a small steamer Vidar sailing between Singapore, Borneo and Celebes. In The Shadow-Line, Conrad describes this decision as "inconsequential". ${ }^{9}$ However, both Najder and Stape observe that the reasons for the decision were quite rational: "The job offered no prospects for the future, the climate was most disagreeable and there

\footnotetext{
${ }^{5}$ Ibid., p. 245.

${ }^{6}$ Ibid.

${ }^{7}$ J. Conrad, "Author's Note" to "The Shadow-Line: A Confession" [in:] idem, Three Sea Stories, pp. 152-153.

${ }^{8}$ Conrad's last long distance voyage as the first officer ended in July of 1893, when he signed off from the clipper "Torrens".

${ }^{9}$ J. Conrad, "The Shadow-Line: A Confession”, p. 160.
} 
was probably no chance of additional earnings. Moreover, the job almost completely cut him off from European civilization." ${ }^{10}$ In addition, Vidar was probably engaged in smuggling weapons, gunpowder and slaves. If Conrad was aware of that, he simply might have wanted to avoid participation in these illegal practices. ${ }^{11}$

Initially, Conrad intended to return to Europe, but he changed his plans when offered the opportunity to take command of the Australian barque Otago, anchored in Bangkok, whose captain had died at sea. ${ }^{12}$ The harbor master who handed over the decision to Korzeniowski was Henry Ellis, who appears as one of the characters in The Shadow-Line. When the newly appointed captain arrived in Bangkok, he tried to set off as soon as possible. Nevertheless, he had to wait for two more weeks, most probably to deal with the formalities connected with the death of the previous captain. What is more, the Otago seamen suffered from malaria, though the burden was not as serious as in the case of the crew described in The Shadow-Line. Like the captain from his novel, Conrad also had some difficulties in leaving the harbour in Bangkok and sailing across the Gulf of Siam; due to the lack of wind, the voyage from Bangkok to Singapore took him three weeks. We do not know if Conrad felt "old" upon his arrival in Bangkok, but it is more than certain that the difficulties he encountered were a new experience for him.

Mastering his skills as a commander, Conrad sailed the southern seas in the following months, staying close to the Australian coast. On $26^{\text {th }}$ March he stopped at Port Adelaide and a few days later resigned from the post of captain of the Otago. The true reasons for Conrad's decision are not clear, and various explanations have been put forward. Jean Aubry suggests that the owners of the ship did not let Korzeniowski sail to South China, while Jocelyn Baines has proposed that Conrad desired to see his uncle Bobrowski. Zdzisław Najder, however, has indicated that the decision resulted from his intellectual and cultural needs:

Once the first charm of commanding a ship faded, the future writer must have felt the dreariness of the sailing in the antipodes, the insufficiency of human contacts restricted as they were to other seamen, so vividly depicted by Langlois, or to the hardly more sophisticated merchants on land. He must have been oppressed by a sense of being cut off from Europe, deprived of newspapers, books, and current news. ${ }^{13}$

The Shadow-Line, published for the first time in 1917, is an artistic attempt to return to the writer's experiences from 30 years before. However, the moment when Conrad finished writing the novel and dedicated it to his son Borys is of considerable importance. It was the time of the nightmarish military conflict fought in Europe, in

${ }^{10}$ Z. Najder, Joseph Conrad: A Chronicle, transl. H. Carroll-Najder, Cambridge: Cambridge UP, 1983, p. 102.

${ }^{11}$ Z. Najder, Życie Josepha Conrada Korzeniowskiego [Joseph Conrad. A Life], Kraków: Wydawnictwo Uniwersytetu Jagiellońskiego, 2014, p. 144.

${ }^{12}$ The former captain of the Otago was John Snadden, a man of good reputation who could not resemble the demonic captain from The Shadow-Line, whose ghost seemed to be responsible for all the misfortunes connected with leaving Bangkok. See N. Sherry. Conrad's Eastern World, Cambridge: Cambridge UP, 1966, p. 50.

${ }^{13}$ Z. Najder, Joseph Conrad: A Chronicle, p. 112. 
which Borys took part. Conscripted in September 1915, after a few months of training, Borys was sent to the front. Serving in the following months, mostly behind the front lines, he was away from direct fighting, but at the very end of the war he suffered from a gas attack. The poisoning caused a shock and nervous disorder which had long-lasting consequences for Borys. Conrad was deeply touched by what had happened to his son at the front, as he wrote to Frank Nelson Doubleday: "We found him greatly matured. But what struck me most was a curious serenity of manner and thought as though nothing on earth could startle him now". ${ }^{14}$ Conrad's attitude towards the First World War was pessimistic, or at least ambivalent since its outbreak in 1914, and the conflict depressed him. He definitely did not share the optimism of some politicians or artists like Herbert George Wells, who believed that it was the "the war to end all wars." ${ }^{15}$ As he wrote in a the letter to Helen Sanderson: "my heart is like lead. I don't think I had many illusions from the first; but this is so different even from a mere half of what one was led to expect." ${ }^{" 16}$ The skepticism and fear connected with the consequences of the First World War resulted from his life-experience, particularly the trauma of his parents' exile and premature death, years spent at sea and the nightmarish time in central Africa, as well as Conrad's unique intuition regarding the politics of great empires, particularly Russia, Germany, France and England.

The literary output of Joseph Conrad had influence on many remarkable artists living in the $20^{\text {th }}$ century. ${ }^{17}$ One of them was surely Stanisław Lem, born in Lviv in 1921. It is not that easy to find traces of Conrad in the works by Stanisław Lem; even though we are certain there are some elements which link the two artists, many traces remain implicit. If we are to reveal them, it seems necessary to examine certain biographical facts and experiences from the time of the artists' youth, particularly those difficult ones, as both Conrad and Lem were affected by totalitarian systems. Conrad was born in 1857, when Poland was erased from the map of Europe. As we know, his parents, particularly his father Apollo, were involved in the revolutionary activities and preparations for the January Uprising of 1863. The arrest of Apollo Korzeniowski in 1861, his subsequent trial and the exile of the whole family to Russia, the premature death of his mother in 1865 , the depression and death of his father a few years later (1869) resulted in a trauma which influenced Conrad's psyche for many years. The difficult experiences of his childhood and youth resulted, among other things, in Conrad's skepticism and pessimism, so noticeable in some of his novels.

${ }^{14}$ J. Conrad, Collected Letters 6:13, [qtd. in:] L. Dryden, Joseph Conrad and H. G. Wells: The Finde-Siecle Literary Scene, Basingstoke: Palgrave Macmillan, 2015, p. 184.

${ }^{15}$ See L. Dryden, Joseph Conrad and H. G. Wells..., pp. 182-186.

${ }^{16}$ Joseph Conrad to Helen Sanderson, $20^{\text {th }}$ April 1918, [quoted in:] Z. Najder, Joseph Conrad: A Chronicle, p. 431.

${ }^{17}$ We can include in the list artists such as Ernest Hemingway, William Faulkner, Graham Greene, Albert Camus, Antoine de Saint-Exupéry; there were also numerous Polish writers who openly admitted their connections with Conrad's fiction: Stefan Żeromski, Maria Dąbrowska, Wit Tarnawski, Jan Parandowski, Antoni Gołubiew, Jerzy Andrzejewski, Jan Józef Szczepański. For more information see S. Zabierowski, Dziedzictwo Conrada w literaturze polskiej [Conrad's Legacy in Polish Literature], Kraków: Oficyna Literacka, 1992. 
It is also worth mentioning that until the end of his life, Conrad felt a deep aversion to the Russian regime, as if accusing it of the misfortunes of many people living in Eastern Europe, including himself. He expressed this aversion and resentment towards totalitarian Russia explicitly in a few of his essays, such as Autocracy and War:

The government of Holy Russia, arrogating to itself the power to torment and slaughter the bodies of its subjects like a God-sent scourge, has been most cruel to those whom it allowed to live under the shadow of its dispensation. The worst crime against humanity of that system which we now behold crouching at bay behind vast heaps of mangled corpses, is the ruthless destruction of innumerable minds. The greatest horror of the world-madness-walked faithfully in its train. Some of the best intellects of Russia, after struggling in vain against the spell, ended by throwing themselves at the feet of that hopeless despotism as a giddy man leaps into an abbys. ${ }^{18}$

or The Crime of Partition:

As to Russia, the third party to the crime, and the originator of the scheme, she had no national conscience at the time. The will of its rulers was always accepted by the people as the expression of an omnipotence derived directly from God. As an act of mere conquest the best excuse for the partition lay simply in the fact that it happened to be possible; there was the plunder and there was the opportunity to get hold of it. Catherine the Great looked upon this extension of her dominions with a cynical satisfaction. ${ }^{19}$

The youthful experiences of Stanisław Lem were different, yet in no way less traumatic. Born in 1921, the son of the well-known Leopolitan laryngologist Samuel Lehm, and graduate of Karol Szajnocha's secondary school, Lem studied medicine at Lviv University, and became known as an extraordinary philosopher, essayist and author of world-famous science-fiction stories. The Second World War broke out when he was just eighteen. Lem was very unwilling to discuss his youth, maintaining that everything he had to say is included in the autobiographical work Highcastle, but the work focuses on the pre-war period, and provides a rather optimistic portrayal of the moment of birth and development of the author's personality, intelligence and imagination. In two extended interviews with Stanisław Bereś (Thus Spoke Lem) and Tomasz Fiałkowski (The World on the Edge), Lem is very reticent about his war experiences. We can learn much more from the two recently published books: Holocaust and the Stars. The Past in the Prose of Stanistaw Lem by Agnieszka Gajewska $^{20}$ and Gravity-Related Tantrums by Tomasz Lem. ${ }^{21}$ They mention, for example, a scene when the Nazi Germans accidentally rounded up a group of people, including young Lem, forcing them to remove the decaying corpses of prisoners shot by the withdrawing Russians. He was convinced that when they had finished the work,

${ }^{18}$ J. Conrad, "Autocracy and War" [in:] idem, The Notes on Life and Letters, https://ebooks.adelaide. edu.au/c/conrad/joseph/c75nl/chapter14.html.

${ }^{19} \mathrm{~J}$. Conrad, "The Crime of Partition" [in:] idem, The Notes on Life and Letters, https://ebooks.adelaide. edu.au/c/conrad/joseph/c75nl/chapter15.html.

${ }^{20}$ A. Gajewska, Zagłada i gwiazdy. Przeszłość w prozie Stanisława Lema [Holocaust and the Stars. The Past in the Prose of Stanisław Lem], Poznań: Wydawnictwo Naukowe UAM, 2016.

${ }^{21}$ T. Lem, Awantury na tle powszechnego ciążenia [Gravity-Related Tantrums], Kraków: Wydawnictwo Literackie, 2016. 
they would be shot too. ${ }^{22}$ Miraculously, he survived; nonetheless the trauma of this experience and further events from the time of the Second World War and the occupation of Lviv remained deep in his psyche and influenced his future writings. Like Joseph Conrad, he developed a rather pessimistic view regarding the reality in which he happened to exist. And it is this characteristic pessimism which seems to be one of the elements linking the fiction of Joseph Conrad and Stanisław Lem.

Certainly, Jan Józef Szczepański, one of Lem's closest friends whom he met in the late 1940s in Cracow, had a considerable influence on the author, and their relationship continued until Szczepański's death in $2003 .{ }^{23}$ Szczepański was fascinated with Joseph Conrad, and particularly with his moral code. Conrad was determined to remain faithful to his ideals: the preservation of consistency and fidelity in the face of hopelessness. Even when the cause for which one fights has been lost, Conrad believed in maintaining dignity and honour. These, are the only virtues which can prevail. ${ }^{24}$ As Szczepański spent hours with Stanisław Lem discussing various issues, and as Lem compulsively read anything that had some artistic or scientific value, it is more than probable that Szczepański "infected" Lem with Conradian ethics and the problems that Conrad tried to depict. To give an example, one may look at Szczepański's account of the fiasco of the Polish military forces in September 1939 in his novel Polish Autumn, ${ }^{25}$ where he described the catastrophe of the country which had just regained independence. The novel contains numerous references to Conrad, including the motif of crossing the shadow-line or the dilemmas occurring in boundary situations. As indicated above, Stanisław Lem was rather unwilling to revisit the trauma he experienced in his youth, nevertheless, reminescences connected with the Second World War reverberate in some of his novels, particularly in The Hospital of Transfiguration, Eden, His Master's Voice. ${ }^{26}$

There are only a few direct references to Joseph Conrad which can be found in Stanisław Lem's fiction. In an extended interview with Stanisław Bereś, Thus Spoke Lem $^{27}$ Stanisław Lem mentions Conrad only once: when asked about the books and writers who had influence on his fiction, he lists the author of The Shadow-Line together with Antoine de Saint-Exupéry, Schopenhauer, Russell, Dostoyevsky and Arthur Stanley Eddington, but does not elaborate on what influence Conrad could have had on his fiction. ${ }^{28}$ Regarding his literary output, Lem mentions Joseph

${ }^{22}$ Stanisław Lem admitted, that this experience is presented in one of his novels, His Master's Voice as a story told by an American-Jewish scholar - professor Rappaport. See A. Gajewska, Zagłada i gwiaz$d y \ldots$, pp. 119-129.

${ }^{23}$ S. Lem, J. J. Szczepański, "Rozmowa na koniec wieku” [Conversation at the End of the Century], Tygodnik Powszechny 1994, no. 8.

${ }^{24}$ See S. Zabierowski, Dziedzictwo Conrada w literaturze polskiej, pp. 172-222.

${ }^{25}$ J. J. Szczepański, Polska jesień [Polish Autumn], Wrocław: Zakład Narodowy im. Ossolińskich, 2015.

${ }^{26}$ For more information see A. Gajewska. Zagłada i gwiazdy ..., 2016.

${ }^{27}$ S. Lem, S. Bereś, Tako rzecze... Lem [Thus Spoke Lem], Kraków: Cyfrant, 2013. Kindle Edition.

${ }^{28} \mathrm{Ibid}$. 
Conrad's Lord Jim in one of his first pieces Hospital of Transfiguration.$^{29}$ Another remark is made in the cycle of Tales of Pirx the Pilot, whose protagonist was "the nicest character in the Polish classical science-fiction". ${ }^{30}$ Precisely, it is included as a slightly ironic, or rather self-ironic remark made when Pirx, still a young pilot, enters the age of maturity and tries to maintain some relationship with his colleagues, dates with friend's sister and prepares for one of the first tasks:

Nevertheless, his rash behaviour continued to nag at him. He had acted impetuously, without any forethought — something for which he seemed to have a special talent. A slap on the rump. Now was that something worthy of a "decent, regular sort of fella"?

He was inclined to think it was. Regardless, the effect of this episode with Matters's sister-whom he had avoided like the plague ever since — was to cure him of his early morning habit of posing before the mirror. Before that, he had sunk so low on several occasions that, not content with one mirror, he had enlisted an additional hand mirror, to find a profile that, however insignificantly, might satisfy his Great Expectations. Fortunately, he was not so consummate an idiot as not to see the absurdity of these asinine poses. Besides, it was not for signs of any masculine sexiness that he was looking-heavens, no!-but grit. For he had read Conrad, and whenever he would ponder, with cheeks aglow, the great galactic silence, the lonely valor of me he always had trouble picturing a hero of eternal night, a loner, having such a-dimplepuss. He soon gave up his morning posing once and for all, thereby demonstrating what superior willpower he had. ${ }^{31}$

Even though the mention contains irony, we can see that the element of Conradian heroism, expressed in terms of the struggle with unfriendly nature and unpredictible circumstances which ultimately shape a true man, is deeply rooted in the consciousness of Lem's protagonist.

As Stanisław Lem is known mainly for his Science Fiction works, it is easy to find numerous links between this kind of fiction and various maritime stories: the voyages of astronauts to other, far-away galaxies and unknown worlds bring to mind sailing on boundless seas and oceans and discovering or exploring new continents; the crews of spacecrafts, locked in confined spaces and organised according to a strict hierarchy, with a captain (commander) and officers having key functions and the greatest responsibility resemble crews on sea vessels. However, as Joseph Conrad cannot just be perceived as a writer of sea fiction, Stanisław Lem is not a typical SF novelist. He treated space and space travel as mere background against which he cast a variety of problems. These include dilemmas regarding contacts with the Other, the loneliness and responsibility of the commander, relationships between the crew members, particularly between the commander and officers responsible for the safety of other seamen, the idiosyncrasies and obsessions of various degrees of seriousness which occur among the crew members often comprising people and androids and finally crucial moments, such as the first command, or critical situations connected, for example,

\footnotetext{
${ }^{29}$ S. Lem, Szpital przemienienia [Hospital of Transfiguration], Kraków: Wydawnictwo Literackie, 2017.

${ }^{30}$ A. Smuszkiewicz, Stanisław Lem, Poznań: Dom Wydawniczy Rebis, 1995, p. 73 (translation mine).

${ }^{31}$ S. Lem, "The Conditional Reflex" [in:] idem, Tales of Pirx the Pilot, transl. L. Iribarne, New York: A Helen and Kurt Wolff Book, 1979. Kindle Edition (emphasis mine).
} 
with an order to use force. ${ }^{32}$ And though, as indicated above, Lem actually does not refer to Conrad directly, Conradian motifs are present in his fiction. One of them is the motif of crossing the metaphorical "shadow-line", shown in some of Lem's works from different perspectives and regarding different, yet crucial moments in the lives of the characters.

Conrad indicated in the "Author's Note" to The Shadow-Line that his first idea was to title the work "First Command", adding that when he changed his mind, "the aim of this piece of writing was the presentation of certain facts which certainly were associated with the change from youth, care-free and fervent, to the more self-conscious and more poignant period of maturer life." 33 Jan Józef Szczepański who was one of the artists rendering the work into Polish added in the final remarks that the title comes from Conrad's observation of the sea and indicates the definite border between two different "worlds": one joyful, flooded with sunshine, another calmer and more serious, remaining in the shadow of the cloud covering the Sun. It is interesting to note that the Polish title of Conrad's masterpiece ${ }^{34}$ is not precise nevertheless its popularity since the moment of publishing has convinced editors not to correct it. Thus the phrase "shadow-line" became one of the so called "winged words". As Stefan Zabierowski notices, its meaning has also been extended and in some cases metaphorically cut off from its Conradian roots; in popular meaning the phrase "to cross the shadow-line" refers not only to crossing the border between youth and maturity, but to passing from one period of life into another, particularly the period that concludes our existence in this world..$^{35}$

In 1961, a few years after Stanisław Lem published his first novels, the author of Solaris finished Return from the Stars. As Jerzy Jarzębski notices, it is not a typical work about traveling into distant space, for it begins in the place where classical works end: Hal Bregg, an Astronaut, having gone through countless dangers, returns safely to Earth. The voyage was to Fomalhault stellar system and it took 10 years, but due to Einstein's time paradox 127 years have passed on Earth. This means that those who survived the expedition find themselves in a completely different reality, as if they had landed on an alien planet. The world has become utopian, people undergo chemical treatment known as betrization which reduces human aggression, and all they desire is to live in peace and prosperity. They are no longer interested in visiting and exploring distant galaxies, hence the return of Bregg's spaceship Prometheus after more than a century, besides a laconic note in media, remains unnoticed.

Nevertheless, Bregg tries to learn how to function in such a society, but he differs from its members in every respect: physical appearance (he's very tall and incredibly

${ }^{32}$ The similarities between the fiction of Conrad and Lem are indicated by a few researchers, for instance Karol Samsel in his article "Stanisław Lem's Conrad. A chosen, albeit problematic filiation," Yearbook of Conrad Studies (Poland) 2015, vol. 10, pp. 151-160.

${ }^{33}$ J. Conrad, "Author's Note" to "The Shadow-Line: A Confession”, p. 152.

${ }^{34}$ The Polish title is Smuga cienia, which literally means "streak of shadow", a collocation which is not normally used in the English language.

${ }^{35}$ See S. Zabierowski, "Granica (czy smuga) cienia?" [The Shadow Line (or Streak)?] [in:] idem, W kręgu Conrada, Katowice: Wydawnictwo UŚ, 2008, pp. 149-162. 
strong), his knowledge of the surrounding realities, and his means of communication. As he states: "This differentness was no mark of distinction but only a barrier to communication, to the simplest exchange of words, hell, to the opening of a door, seeing as doorknobs had ceased to exist — what was it? — some fifty or sixty years earlier." 36

In going ashore, Conrad's character finds himself in a world he already knows. On returning to Earth, however, Hal Bregg feels as if he were on some other planet. Bregg is not so much concerned with commanding a ship and taking decisions, where he can rely on his skills and experience, but with adaptation to the conditions prevailing in this "brave new world." 37 What is more, Bregg is one of the few people on Earth who is not betrizated, which means that on the one hand he may be dangerous for other people, but on the other hand he is able to take risks and make sacrifices for others. In one of his conversations with Eri, a woman he meets and falls in love with, Bregg mentions some of the extreme forms of encounter during his voyage and emphasizes the necessity of cooperation with other crew members: loyalty, fidelity, responsibility for others and the mission itself, values so important for Joseph Conrad. Bregg is also ready to risk his own life to save his friend, and though he fails, the very attempt and the ensuing moral burden comprise the essence of humanity, which remains unknown and incomprehensible to the betrizated people. It seems, therefore, that the astronauts from Prometheus who returned from the stars are the only people on Earth who have crossed the Conradian shadow-line. They have matured, enjoyed successes and experienced failures which have challenged their sense of morality and taught them responsibility. Back on Earth, Hal Bregg does resemble the young captain from The Shadow-Line who hears the wise words of Captain Giles: "a man should stand up to his bad luck, to his mistakes, to his conscience and all that sort of thing." ${ }^{38}$ Ironically, the astronauts who survived the voyage to the stars learn that the expedition was not expected to make a scientific breakthrough or lead to contact with another civilization; it was nothing more than a romantic pursuit of something unattainable, an attempt to prove the impossible:

"Contact with other civilizations? Whoever said anything about that? None of us, not one of the scholars, Not Merquier, not Simonadi, not Rag Ngamieli-no one; no expedition counted on any such contact, and therefore all that talk about fossils flying through space and the perpetually delayed galactic mail, it's a refutation of an argument that no one ever made. What can one get from the stars? And of what use was Amundsen's expedition? Or Andree's? None. The only clear benefits lay in the fact that they had proved a possibility. That it could be done. Or, more precisely, that it was, for a given time, the most difficult attainable thing. I don't know if we even did that much, Bregg. I really don't. But we were there." ... I am not saying that the stars are only an excuse. Neither was the pole; Nansen and Andree needed it. ... Everest meant more to Mallory and Irving than the air itself. ... You know what our problem is, Bregg? The fact that we made it and are sitting here. Man always comes back empty-handed ...."39

${ }^{36}$ S. Lem, Return from the Stars, transl. B. Marszal, F. Simpson, New York: A Helen and Kurt Wolff Book, 1961. Kindle Edition.

${ }^{37}$ We can find many similarities between Lem's novel and Huxley's masterpiece Brave New World.

${ }^{38}$ J. Conrad, "The Shadow-Line: A Confession", p. 245.

${ }^{39}$ S. Lem, Return from the Stars, op. cit. 
In uttering these words, Thurber, Bregg's former commander, expresses his scepticism or even pessimism, typical for both Conrad and Lem. Nonetheless, it does not stop him from preparing another expedition, assuming that some of the Prometheus's crew members might want to take part in it, including Bregg's closest friend, Olaf. In a sense, they want to escape from the reality that has proved to be unacceptable for them. Hal Bregg, however, makes a more difficult decision and stays on Earth. Like Conrad, he decides to give up his wandering and begin a new chapter in his life. Conrad did that because he wanted to fulfill his aesthetic and artistic desires and hoped for the security and domesticity of home, for a "port after stormie seas." ${ }^{\text {"40 }}$ The protagonist of Return from the Stars stays because he dreams for a peaceful life at the side of the woman he loves, whose sincere feelings link two different worlds, the past and the present, despite their civilizational, social and cultural differences. ${ }^{41}$

Three years after the publication of Return from the Stars, Lem wrote another novel about space travel to a remote place, The Invincible. The title comes from the name of a huge space cruiser, "the largest vessel of the fleet stationed at the base in the Lyra constellation," ${ }^{42}$ which flies to rescue a missing twin spacecraft - the Condor. After landing, the crew consisting of the commander, officers, engineers and scientists begin the search. They also examine the planet, and when they try to find out more about the conditions and life forms there, one of the groups discovers strange constructions resembling the deserted ruins of an ancient town. The Condor is soon found, and it appears that all its crew have died in mysterious circumstances. Further exploration of the planet reveals some answers to questions regarding the tragic fate of the Condor: the astronauts were in fact killed by miniature, insect-size robots, which they call flies, and which are responsible for the extinction of life on the planet's mainland. It turns out that the mechanical flies have the ability to join and form huge clouds, creating a magnetic field strong enough to erase the memory of living organisms and destroy the processors of electronic devices. Soon afterwards, the crew of the Invincible has to face an enemy more powerful than any war machinery known to man, including the Cyclops, a mechanical monster shooting antimatter which destroys everything around in the blast of annihilation. However, unable to prevent losses, many of the Invincible crew members share the fate of the Condor staff.

As Jerzy Jarzębski asserts in the afterword to The Invincible, ${ }^{43}$ the battle scenes contained in the novel would provide perfect material for a large scale Hollywood production. However, it is not this element that determines the novel's quality and significance, but the moral dilemmas it presents, as to whether to stay on the planet and continue the search for the missing crew members, who perhaps are still alive, or

${ }^{40}$ Quote from Edmund Spenser's The Faerie Queene, used by Conrad as the epigraph to The Rover, these words are also etched on his tombstone in Canterbury.

${ }^{41}$ It is worth to add that many years later Lem expressed very critical opinions about Return from the Stars stating, among other things, that it was definitely too sentimental. Full commentary available online: english.lem.pl/works/novels/return-from-the-stars.

${ }^{42}$ S. Lem, The Invincible, transl. B. Johnston, Kraków: Wydawnictwo Literackie, 2017. Kindle Edition.

${ }^{43}$ J. Jarzębski, "Cały ten złom” [All that Scrap], Afterword to S. Lem, The Invincible, https://solaris. lem.pl/ksiazki/beletrystyka/niezwyciezony/96-poslowie-niezwyciezony. 
to abandon all risk and fly away. The decision, as always in such circumstances, belongs to the commander, an experienced astronaut, who is consumed by doubts:

At the same time Horpach [the commander] was faced with the dilemma of what to do next. The situation was sufficiently clear for him to be able to return to base with information that explained the tragic end of the Condor and justified turning back. ...

"I didn't know what to do."

There was something shocking in this. At one level Rohan was aware that for several days now the captain had been as much at a loss as the rest of them; but at this moment he understood that this was not true knowledge, because at root he had trusted that the commander could see several moves ahead, more than anyone else, because it had to be that way. While now, suddenly, Horpach's nature had been revealed to him as it were doubly, because he saw his halfnaked torso, his exhausted body with its unsteady hands, something that had not previously entered his consciousness, and at the same time he had heard words that confirmed the realness of his discovery. ${ }^{44}$

Rohan's opinion with regard to his captain changes when he takes it upon himself to search for his missing colleagues, who are probably dead. Although he is involved, as Jerzy Jarzębski stated, "in a weird psychomachia with his commander," 45 and does not consider himself to be a hero, Rohan passes the test for responsibility and humanity. He crosses the shadow-line-risking his own life, he looks for the missing crew members moving silently behind the enemy lines in order not to arouse its mechanical vigilance. It seems that the key moment here is the moment when Rohan makes the decision: for a while he becomes the commander of the Invincible, understanding the weight of the problem and the responsibility he bears:

Rohan saw him and did not see him at the same time. His first reaction was anger toward Horpach, who had treated him so despotically, giving him the right, or actually the duty, to make a decision, binding him with his word, at the same time accepting full responsibility in advance. ... As long as he had been at Horpach's side, he had believed they ought to take off without delay. Now he felt he could never bring himself to issue such an order. He knew that that would not be the end of the Regis affair, but its beginning. It wasn't about responsibility to the base. Those four men would have continued to be present on the ship, and things would never have been the same. The crew wanted to leave. But he recalled his nocturnal wanderings and realized that after a certain time they'd begin to think about it, then they'd start talking. They'd say: "You see? He took off, leaving four men behind." And nothing else would matter. Every man had to know that the others would not abandon him, under any circumstances. That everything could be lost, but you had to have the crew on board - alive or dead. This principle did not appear in the regulations. But without it it wouldn't have been possible to fly. ${ }^{46}$

The presented quandaries of the experienced commander Horpach, who resembles a little the Conradian Captain Giles, draw our attention to the problem of the commander's loneliness when he has to take the most difficult decisions. The same problem appears in Conrad's The Shadow-Line several times:

\footnotetext{
${ }^{44} \mathrm{~S}$. Lem, The Invincible, op. cit.

${ }^{45}$ J. Jarzębski, "Cały ten złom".

${ }^{46} \mathrm{~S}$. Lem, The Invincible, op. cit.
} 
There were days when I used to remember Captain Giles with nothing short of abhorrence. His confounded acuteness had let me in for this job; while his prophecy that I "would have my hands full" coming true, made it appear as if done on purpose to play an evil joke on my young innocence.

Yes. I had my hands full of complications which were most valuable as "experience." People have a great opinion of the advantages of experience. But in this connection experience means always something disagreeable as opposed to the charm and innocence of illusions. ${ }^{47}$

\section{$[\ldots]$}

"Is there no chance at all to get under way, sir?"

"What's the good of letting go our hold of the ground only to drift, Mr. Burns?" I answered. He sighed and I left him to his immobility. His hold on life was as slender as his hold on sanity. I was oppressed by my lonely responsibilities. I went into my cabin to seek relief in a few hours' sleep, but almost before I closed my eyes the man on deck came down reporting a light breeze. Enough to get under way with, he said. ${ }^{48}$

\section{$[\ldots]$}

Every stitch of canvas has been on her since we broke ground at the mouth of the Mei-nam, fifteen days ago ... or fifteen centuries. It seems to me that all my life before that momentous day is infinitely remote, a fading memory of light-hearted youth, something on the other side of a shadow. Yes, sails may very well be blown away. And that would be like a death sentence on the men. We haven't strength enough on board to bend another suit; incredible thought, but it is true. Or we may even get dismasted. Ships have been dismasted in squalls simply because they weren't handled quick enough, and we have no power to whirl the yards around. It's like being bound hand and foot preparatory to having one's throat cut. And what appals me most of all is that I shrink from going on deck to face it. It's due to the ship, it's due to the men who are there on deck - some of them, ready to put out the last remnant of their strength at a word from me. And I am shrinking from it. From the mere vision. My first command. Now I understand that strange sense of insecurity in my past. I always suspected that I might be no good. And here is proof positive. I am shirking it. I am no good. ${ }^{49}$

Like the protagonist of The Shadow-Line commanding his ship for the first time, Rohan is also anxious and filled with fear when he goes out to search for the missing colleagues. He knows the power of the magnetic cloud and knows what it can do to a human brain. However, Rohan changes his attitude towards the planet and its necrosphere at the most dramatic moment, when facing the mechanical flies secured only by a net attenuating electrical impulses produced by his brain. He's no longer afraid and believes that instead of leading to another confrontation and taking unnecessary risks they should fly away, leaving behind those forms of existence which are beyond human understanding and with which it is therefore impossible to make contact. Rohan matures enough to bear responsibility not only for his crew members, but for whole civilizations, even if they do not contain biological life forms.

\footnotetext{
${ }^{47}$ J. Conrad, "The Shadow-Line: A Confession", p. 201.

${ }^{48}$ Ibid., p. 207.

${ }^{49}$ Ibid., p. 228-229.
} 
The motif of crossing the Conradian shadow-line in Stanisław Lem's science fiction is also present in some of the short stories collected in Tales of Pirx the Pilot. ${ }^{50}$ The stories seem to be independent, linked only by the title protagonist. Surprisingly, Pirx is not a hero who tries to go beyond the frontier of human understanding of the universe, but an "ordinary" pilot, dreaming, like Lord Jim, about great adventures and heroic deeds, while fulfilling conscientiously his everyday duties and climbing the professional ladder like Conrad. He also has "ordinary" failings and weaknesses, like timidity or an inferiority complex when faced with overconfident colleagues.

Almost all the tales put Pirx to some test, be it a mystery he has to solve or a difficult problem he has to deal with. The only exception is the tale entitled "The Albatross," where Pirx is an observant of a tragic accident which takes place in space. ${ }^{51}$ Each of the tests results in gaining new experience, which in turn results in acquiring the skill of non-standard thinking, necessary in critical situations. However, Pirx crosses his shadow-line much later than Conrad's protagonist, and his boundary is not connected with the first command (Pirx is an independent pilot, though a very young one, flying small vessels from the very first story of the series, entitled "The Test"), but with a situation in which he is asked to take part in an experimental flight, during which he is to supervise and evaluate a crew consisting of men and human-like robots called "nonlinears". The problem is that Pirx cannot differentiate between them. This evaluation is crucial for the decision of whether to introduce these robots, which are stronger, more efficient, and lacking many human weaknesses, as regular staff for long-distance flights. The actual test takes place when Goliath, their spacecraft, passes through the Cassini Division-a relatively narrow gap between two of the rings of Saturn. It is then that one of the robots, Calder, who has earlier written a letter in which he reveals plans to dominate the human race like "an electronically wired Genghis Khan," 52 leads to a situation in which the lives of all the humans on board are endangered because of the excessive g-load. Calder's logical plan falls apart due to the non-standard behaviour of Pirx, who against the expectations of the robot allows him to act to the very end, which put all the people on board Goliath under extreme danger. This lack of decision shows the illogical superiority of humanity over seemingly ideal artificial intelligence, as it reveals Calder's true intentions. A simple, yet crucially important moral impulse turns out to be the key factor which enables the distinguishing of humans from robots. The awareness of this fact enables Pirx to cross his shadow-line, as now, being aware of people's weak-

${ }^{50}$ Stories about the adventures of Pirx the Pilot appeared in different collections between 1959 and 1973. They were published in a single volume for the first time in 1968 as Opowieści o pilocie Pirxie (Kraków: Wydawnictwo Literackie, 1968). This collection was translated to English in two parts: Tales of Pirx the Pilot (1979) and More Tales of Pirx the Pilot (1982).

${ }^{51}$ In this tale Pirx is a passenger on a spaceship Transgalactic, which changes its course in order to help the crew of another spacecraft whose nuclear engine explodes. The very rescue operation resembles a situation on a sea, when some ship is sinking, and other vessels, being close to, it rush in order to rescue the people who are in danger.

${ }^{52}$ S. Lem, "The Inquest" [in:] idem, More Tales of Pirx the Pilot, transl. L. Iribarne, New York: A Helen and Kurt Wolff Book, 1982. Kindle Edition. 
nesses and vices, he fully accepts them and realizes that in fact they are the essence of humanity:

What is the thing called human nature? Maybe that's all it really means-being irrational and decent and, yes, morally primitive, blind to the final links in the chain. Nothing "decent" or "irrational" about computers, that's for sure. Which would mean that we ... our human nature is the sum of all our defects, flaws, imperfections, of what we want to be but can't or don't know how to be: the gap between our ideals and those same ideals as a reality. ${ }^{53}$

The humanity test is not the only shadow-line Pirx crosses in his career of pilotastronaut. In the last story included in Tales of Pirx the Pilot entitled "Ananke," Pirx, by now a prime-aged commodore bearing a little resemblance to Captain Giles, faces another challenge. The story is about the catastrophe of the Ariel, a huge superfreighter on the surface of Mars. Pirx, being one of the witnesses, joins the committee which is to explain the causes of the disaster as an expert pilot. A detailed description of the investigation serves as a pretext for the author to share his reflections regarding the flow of time, generational change and reassessment of youthful dreams. Mars, the planet where the disaster of the Ariel takes place, becomes a symbol of these reflections:

Mars, the embodiment of spent illusions - scoffed, ridiculed, but precious. Any other run would have been better. All that past glamorizing of the project was sheer hokum; the chances for colonization a fiction. Oh, Mars had fooled them all; besides, it had been fooling people for a hundred odd years ... Mars seemed to have quit, not caring whether it kept its word, unconcerned with appearances. The closer one got to it, the more it lost its solid red exterior, the more it ceased to be the emblem of a war god, the more it revealed its drabness, spots, stains, its lack of any lunar or Earthlike contour: a grey-brown blight, rocked by eternal wind. ${ }^{54}$

The story is, in a sense, a parting from the romantic vision of space exploration and conquest, and with the naivety of Science Fiction. The reader notices that it is a prelude to Fiasco, the last and most pessimistic novel by Stanisław Lem with Pilot Pirx as one of the characters (at the very beginning of the work Pirx dies in an attempt to save his colleague). "Ananke" is also a tale where Lem directly refers to the motif of crossing the shadow line. However, in this story Lem treats it not as a boundary between youth and maturity, but between maturity and old age. He clearly emphasizes this point, reaffirming that ageing means the verification of one's youthful dreams:

In his late thirties, pushing forty: the shadow line. Time to accept the terms of the unsigned contract, there without the asking; the knowledge that what binds others applies to you, too, that there are no exceptions to the rule: though it was contrary to nature, one has to grow old. So far, only the body was secretly obeying, but that wasn't enough anymore. Now one had to ascend it. Youth made its own unalterability the rule, the basic premise: I was childish, immature, but now I am my true self, and that's the way I'll stay. This was the joke at the very heart of existence, whose discovery was more a cause of amazement than of alarm - a sense of outrage born of

\footnotetext{
${ }^{53}$ Ibid.

${ }^{54}$ S. Lem, “Ananke" [in:] idem, More Tales of Pirx the Pilot, op. cit.
} 
the realization that the game we've been forced to play is a hoax. The contest was to have been different; after the initial shock, the anger, the resistance, came the slow negotiations with one's self, with one's body: no matter how smooth and imperceptible the aging process, we can never reconcile ourselves to it rationally. ${ }^{55}$

\section{$[\ldots]$}

The shadow line is not a memento mori but is in many respects worse, a vantage point from which to see our prospects diminished. That is, the present is neither a promise nor a waiting room, neither a preface nor a springboard for great hopes, because the terms have been imperceptibly reversed. The so-called training was an irrevocable reality; the preface - the story proper; the hopes - fantasies; the optional, the provisional, the momentary, and the whimsical - the true stuff of life. What hasn't been achieved by now will never be; and one has to reconcile oneself to this fact, quietly, fearlessly, and, if possible, without despair. ${ }^{56}$

In the above fragments one can see that a peculiar transformation takes place in the mind of the protagonist. Pirx is fully aware of his experience, but he is also aware of his own limitations. Like Captain Giles, he no longer thinks about heroic deeds, discoveries and conquests; he's ready to "live at half-speed"57; he is also much more tolerant towards younger colleagues or human imperfection. Captain Giles has a different attitude towards his Chief Steward than the protagonist of The Shadow-Line, and Pirx develops the same kind of tolerance: he does not get irritated when younger colleagues, implicitly trusting computers and technology, call him a "fossil," "anticomputer," "reactionary." ${ }^{58}$ Paradoxically, it is this unconditional trust in the reliability of technology, electronics and computers that leads to the catastrophe of the Ariel. Each computer is programmed by a man and thus contains traces of his personality, including habits or obtrusiveness. Hence, in critical situations it is sometimes better to rely on intuition and moral principles rather than on uncritical belief in soulless machines and electronics.

Looking again at the works by Stanisław Lem, the examples of which are presented above, we can see that although their action takes place in outer space, or on different planets, the discourse of science fiction serves as mere background, created by the author in order to discuss moral issues or complex philosophical or ethical problems. As it is a mistake to treat Joseph Conrad purely as a writer of marine fiction, so Stanisław Lem cannot only be labeled a science-fiction writer. We can also see that though Lem rarely refers to other artists, he was surely inspired by them and included various motifs in his fiction. The Conradian shadow-line, so noticeable in Eden, The Invincible, or Tales of Pirx the Pilot is one of the best examples.

\footnotetext{
${ }^{55}$ Ibid.

${ }^{56}$ Ibid.

${ }^{57}$ J. Conrad, "The Shadow-Line: A Confession", p. 245.

${ }^{58}$ S. Lem, “Ananke”, op. cit.
} 


\section{WORKS CITED}

Conrad, J., “Autocracy and War" [in:] idem, The Notes on Life and Letters, https://ebooks.adelaide. edu.au/c/conrad/joseph/c75nl/chapter14.html (access: 28 December 2017).

---------, “Author's Note" to The Shadow-Line: A Confession [in:] idem, Three Sea Stories, Ware: Wordsworth Editions Limited, 1998.

---------, "The Crime of Partition" [in:] idem, The Notes on Life and Letters, https://ebooks.adelaide.edu.au/c/conrad/joseph/c75nl/chapter15.html (access: 28 December 2017).

Editions Limited, 1998.

Dryden, L., Joseph Conrad and H. G. Wells. The Fin-de-Siecle Literary Scene, Basingstoke: Palgrave Macmillan, 2015.

Gajewska, A., Zagłada i gwiazdy. Przeszłość w prozie Stanisława Lema, Poznań: Wydawnictwo Naukowe UAM, 2016.

Jarzębski, J., "Cały ten złom”, Afterword to S. Lem, The Invincible, https://solaris.lem.pl/ksiazki/ beletrystyka/niezwyciezony/96-poslowie-niezwyciezony (access: 28 December 2017).

Lem, S., "Ananke" [in:] idem, More Tales of Pirx the Pilot, transl. L. Iribarne, New York: A Helen and Kurt Wolff Book, 1982. Kindle Edition.

-----------, Niezwyciężony, Kraków: Wydawnictwo Literackie, 2015.

----------, Opowieści o pilocie Pirxie, Kraków: Wydawnictwo Literackie, 2000.

----------, Powrót z gwiazd, Kraków: Cyfrant, 2012. Kindle Edition.

---------, Return from the Stars, transl. B. Marszal, F. Simpson, New York: A Helen and Kurt Wolff Book, 1961. Kindle Edition.

-----------, Szpital przemienienia, Kraków: Wydawnictwo Literackie, 2017.

---------, "The Conditional Reflex" [in:] idem, Tales of Pirx the Pilot, transl. L. Iribarne, New York: A Helen and Kurt Wolff Book, 1979. Kindle Edition.

---------, "The Inquest" [in:] idem, More Tales of Pirx the Pilot, transl. L. Iribarne, New York: A Helen and Kurt Wolff Book, 1982. Kindle Edition.

-----------, The Invincible, transl. B. Johnston, Kraków: Wydawnictwo Literackie, 2017. Kindle Edition.

Lem, S., Bereś, S., Tako rzecze... Lem, Kraków: Cyfrant, 2013. Kindle Edition.

Lem, S., Szczepański, J. J., "Rozmowa na koniec wieku”, Tygodnik Powszechny 1994, no. 8.

Lem, T., Awantury na tle powszechnego ciążenia, Kraków: Wydawnictwo Literackie, 2016.

Najder, Z., Joseph Conrad: A Chronicle, transl. H. Carroll-Najder, Cambridge: Cambridge UP, 1983.

-----------, Życie Josepha Conrada Korzeniowskiego, vol. I and II, Kraków: Wydawnictwo Uniwersytetu Jagiellońskiego, 2014.

Samsel, K., "Stanisław Lem's Conrad. A chosen, albeit problematic filiation", Yearbook of Conrad Studies (Poland) 2015, vol. 10.

Sherry, N., Conrad's Eastern World, Cambridge: Cambridge UP, 1966.

Shidara, Y., "Conrad and Bangkok" [in:] Journey, Myths and the Age of Travel: Joseph Conrad's

Era, ed. K. Hansson, Karlskrona: University of Karskrona, 1998.

Smuszkiewicz, A., Stanisław Lem, Poznań: Dom Wydawniczy Rebis, 1995.

Szczepański, J. J., Polska jesień, Wrocław: Zakład Narodowy im. Ossolińskich, 2015.

Zabierowski, S., Dziedzictwo Conrada w literaturze polskiej, Kraków: Oficyna Literacka, 1992.

----------, “Granica (czy smuga) cienia?” [in:] idem, W kręgu Conrada, Katowice: Wydawnictwo Uniwersytetu Śląskiego, 2008. 